\title{
Up-regulation of Human nm23-H2/NDP Kinase B in Early Phase of Regenerating Transgenic Mouse Hepatocyte
}

\author{
In Hwan Lee \\ Department of Anatomy and Institute for Medical Genetics, \\ School of Medicine Keimyung University
}

\begin{abstract}
The kinetics and subcellular localization of nm23-Ml and -M2 was reported in in vivo regenerating mouse liver cells after partial hepatectomy (Lee et al. 1997a). On the human nm23- $\mathrm{H} 2$ transgenic mice, the kinetics of murine types of nm23 and mitotic index were very similar to results from ordinary mice B6, whereas the kinetics of human type of $\mathrm{nm} 23$ was responded strongly and shortly in early phase of regeneration. In subcellular study, all fractions of $\mathrm{nm} 23-\mathrm{H} 2$ protein at $6 \mathrm{hr}$ after partial hepatectomy were increased to very high level and decreased soon day 1. These studies suggest that exogenous DNA sequence nm23-H2 expressed immediately in early phase of hepatocyte regeneration, and in short term duration comparing with native murine type of $\mathrm{nm} 23$. This analysis might include that another cellular cofactor(s) is(are) necessary for human type nm23 expression in regenerating mouse hepatocyte in playing a role as a transcription factor, or that is not associated with any cellular cofactors in organ crisis.
\end{abstract}

Key words : nm23/NDP kinase, Transgenic mice, Regeneration, Mouse, Hepatocyte, Transcription effect

\section{INTRODUCTION}

In mammalians such as mice, rats, and humans, the presence of two isotypes of nm23/NDP kinase has been identified (Urano et al. 1992, Okada et al. 1996, Ishikawa et al. 1992). These two isotypes encode 17 $\mathrm{kDa}$ proteins that are high homology of $82 \sim 89 \%$ in amino acid bases and nucleotide bases (Okada et al. 1996, Gilles et al. 1991) and display quite similar NDP kinase activity in vitro (Stahl et al. 1991) and form hexamers with a random association of two isotypes in the cells (Postel et al. 1996).

The nm23/NDP kinase expression correlates inversely with the metastatic potential of several rodent

* 본 연구는 1998년도 의학유전연구소 특수연구비로 이루 어졌음 tumors (Steeg et al. 1988) and human breast carcinoma and human hepatocellular carcinoma (Bevilacqua et al. 1989). Transfection of nm23 cDNA into highly metastatic murine $\mathrm{K}-1735-\mathrm{TK}$ melanoma cells results in significant reduction of metastasis. However in colorectal carcinoma, no significant association was found between nm23 expression and metastatic potential, whereas in childhood neuroblastoma, overexpression and mutation of $\mathrm{nm} 23$ were associated with advanced tumors.

Increased expression of nm23-H2/NDP kinase associated with cellular proliferation has been observed in activated lymphocytes(Gilles et al. 1991, Caligo et al. 1995) and in a variety of cell lines (Igawa et al. 1995, Keim et al. 1992). The facts that the differentiation of murine myeloid leukemia was inhibited by nm23/NDP kinase (Okabe-Kado et al. 1995), and differentiation of human hematopoietic cell lines was 
associated with decreased expression of the gene (Yamashiro et al. 1994) suggest that nm23/NDP kinase participates in cellular proliferation/differentiation.

The nm23-H2/NDP kinase B encodes PuF, which transactivates $\mathrm{c}-$ myc oncogene, catalyzes the shuttling of $\gamma$-phosphates (Postel et al. 1996). In this study, the activation of exogenous DNA sequence nm23$\mathrm{H} 2 / \mathrm{NDP}$ kinase $\mathrm{B}$ in transgenic mouse was analyzed. To induce proliferation of hepatocyte, partial hepatectomy $(50 \pm 2 \%)$ was done. In early phase of regeneration at $6 \mathrm{hr}$ after partial hepatectomy, increased nm23H2/NDP kinase B molecule was found, especially distinguished level in the all fractions including nuclear fraction.

\section{MATERIALS AND METHODS}

\section{Liver tissue}

8 -week-old B6 male mice and $\mathrm{nm} 23-\mathrm{H} 2$ transgenic mice were partially hepatectomized $(50 \pm 2 \%)$ under anesthesis (Higgins and Anderson 1931). The transgenic mice were kindly provided from Department of Oncology, Nagasaki Medical School. Six hours, $12 \mathrm{hr}, 1 \mathrm{~d}, 3 \mathrm{~d}, 5 \mathrm{~d}$, and $15 \mathrm{~d}$ after partial hepatectomy, liver tissues were taken out. Sham operation was done for control in which just the abdominal wall was opened and the liver was exposed to air.

\section{Cell fractionation and protein extraction}

A detailed fractionation procedure has been described elsewhere (Dignam et al. 1983). Briefly, for the nuclear fractionation, washed cells or tissues were minced in the lysis buffer I [0.5\% NP-40, $0.01 \mathrm{M}$ Tris- $\mathrm{HCl}$ (pH 7.5), 0.15 M NaCl, 0.01 $\mathrm{M} \mathrm{MgCl}_{2}, 1.5$ mM phenylmethyl-sulfonylfluoride (PMSF) (Sigma, St. Louise, MO)]. The lysate was centrifuged for 10 $\min$ at $3,500 \mathrm{rpm}$ in a microcentrifuge at $4^{\circ} \mathrm{C}$. The pellet was resuspended in the lysis buffer I and sonicated at $50 \%$ of duty cycle for $15 \mathrm{sec}$ twice. After cen- trifugation for $15 \mathrm{~min}$ at $12,000 \mathrm{rpm}$, the supernatant was used as a nuclear fraction. For cytoplasmic and membrane fractions, washed cells or tissue were minced in the lysis buffer II (same as the lysis buffer I except NP-40) and sonicated, then centrifuged for 10 $\min$. The supernatant was centrifuged for $40 \mathrm{~min}$ at $15,000 \mathrm{rpm}$. The supernatant was used as a cytoplasmic fraction. The pellet was resuspended in the lysis buffer I and centrifuged again for $5 \mathrm{~min}$ at $12,000 \mathrm{rpm}$. The supernatant was used as a membrane fraction.

\section{Antibodies and Western blot analysis}

Expressions of nm23-M1, -M2, and - H2 were fractionated by SDS-PAGE and analyzed by immunoblotting with monoclonal antibodies (Sambrook et al. 1987). Antibodies specific for each isotype of $\mathrm{nm} 23 /$ NDP kinase were prepared as described (Baba et al. 1995) and kindly provided from Dr. Shiku, Department of 2nd Internal Medicine, Mie Medical School; anti nm23-M1, M1-45; anti nm23-M2, M2-435; anti nm23-H2, H2-439.

\section{Mitotic index in regenerating hepatocytes}

The mitotic index was checked after partial hepatectomy. Four hours before the animal was sacrificed, $1 \mu \mathrm{g}$ of colchicin/g of body weight was injected intraperitoneally. Mitotic metaphase cells were counted from the portal to central hepatic area in liver acinus.

\section{RESULTS}

\section{Changes of nm23-M1 and -M2 levels during the hepatic regeneration}

Experimental animals, B6 mice and exogenous human gene $\mathrm{nm} 23-\mathrm{H} 2$ in germ line were transferred. The native murine $\mathrm{nm} 23-\mathrm{M} 1$ and $\mathrm{M} 2$ genes were well expressed in B6 mice. After partial hepatectomy, the expressions of nm23-M1 and M2 in regenerating liver tissues were analyzed by Western blotting (Fig. 1). In the early phase of the regeneration (before day 
3), the expressions of two isotypes rapidly increased, then slowly decreased to the original level. Expression of nm23-M1 reached the peak on $12 \mathrm{hr}$, while that of nm23-M2 reached a peak on day 1 . Especially, the kinetics of nm23-M2 was very similar to that of following mitotic index.

The number of metaphases in the regenerating mouse liver tissue was also counted (Fig. 2). The mitotic response to the partial hepatectomy was in general compatible with the changes of expression of both isotypes of nm23. Mitotic index (MI) at sham operation and at $6 \mathrm{hr}$ were $0.06 \sim 0.1 \%$. A highly increased level of MI, $0.7 \%$ was found at $12 \mathrm{hr}$ and then reached maximum levels, $3.2 \%$ at day 1 , and was maintained until day 5 , then declined by day 15 .

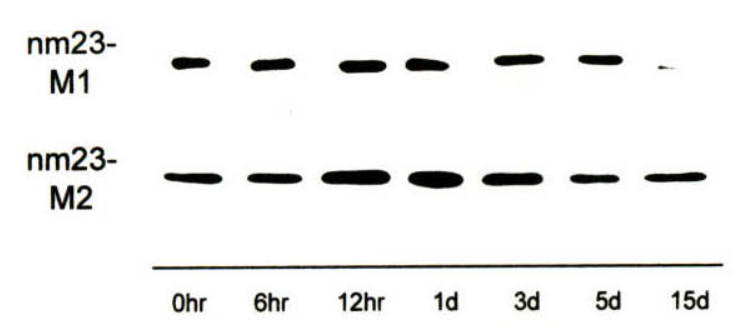

Fig. 1. Expressions of nm23-M1 and -M2 during liver regeneration after partial hepatectomy with time course. Hepatocyte lysate were prepared at indicated points after partial hepatectomy. Ten $\mu \mathrm{g}$ of protein extracts were separated on a $12 \%$ gel and immunoblotted as described in Materials and Methods.

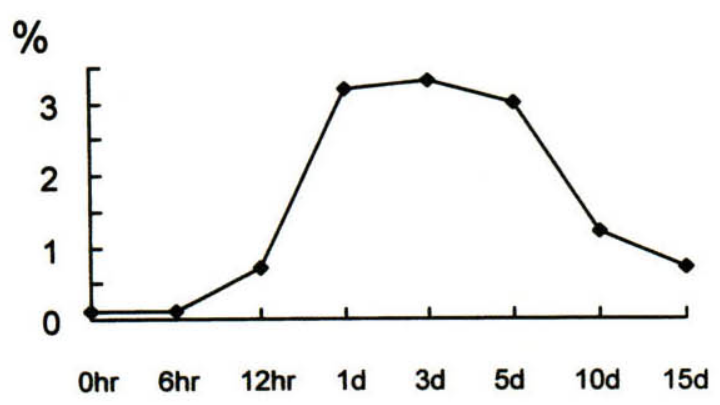

Fig. 2. Mitotic index with time course after partial hepatectomy. Percent of cells at metaphase were counted at the time indicated as described in Materials and Methods.

\section{Subcelluar distribution of $\mathbf{n m} 23$ in the regenerating hepatocytes}

As shown in Fig. 3, the subcellular distribution of $\mathrm{nm} 23$ protein was determined. The relative expressions of nm23-M1, -M2, and - $\mathrm{H} 2$ increased in all proliferative fractions when compared $0 \mathrm{hr}$ samples. All nuclear fractions of three genes showed a peak increased value at $6 \mathrm{hr}$ and returned at day 1, whereas cytoplasmic and membrane fractions were sustained. Exogenous human nm23-H2 expression showed a peak value at $6 \mathrm{hr}$ in all fractions and returned to sham operation level on day 1 . In densitometry, 3.62 fold in

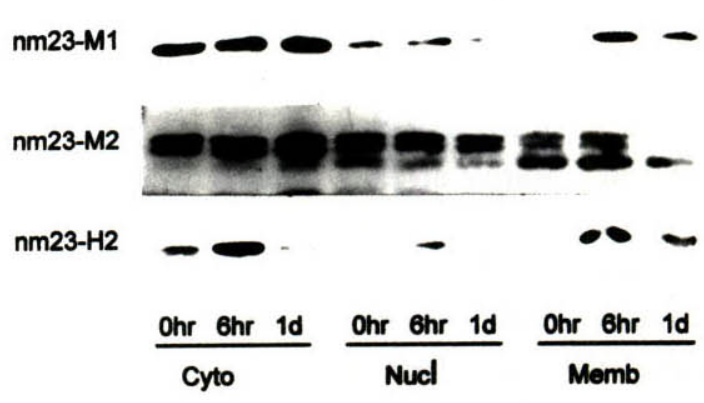

Fig. 3. Subcellular distribution of nm23-M1, $-\mathrm{M} 2$, and $-\mathrm{H} 2$ proteins during mouse liver regeneration. Western blotting of fractionated proteins; Fractionation and immunoblotting were performed as described in Materials and methods. Cyto, cytoplasmic fraction; Nucl, nuclear fraction; Memb, membrane fraction.

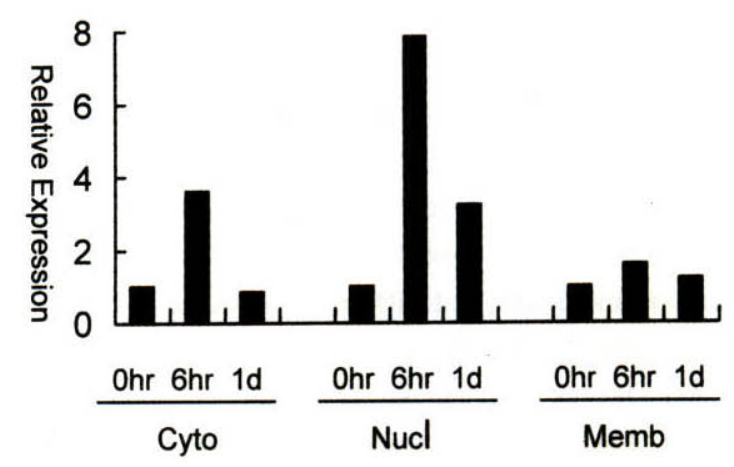

Fig. 4. Relative subcellular distribution levels of human nm23$\mathrm{H} 2$ protein based on the bands in Fig. 3 . 
cytoplasmic fraction, 7.84 fold in nuclear fraction, and 1.65 fold in membranous fraction were shown (Fig. 4).

\section{DISCUSSION}

Increased expression of nm23/NDP kinase molecules in association with cellular proliferation in various cells and cancer progress has been reported (Igawa et al. 1995, Keim et al. 1992). In in vitro transcription effect of nm23/NDP kinase on c-myc oncogene for proliferation, murine $\mathrm{nm} 23$ worked in murine cell lines, but human nm23 (Lee et al. 1997b). In in vivo model, human $\mathrm{nm} 23$ gene transferred mice, the association of exogenous human $\mathrm{nm} 23$ expression with murine hepatocyte proliferation and intracellular localization of two isotypes of nm23/NDP kinase was studied by utilizing isotype specific monoclonal antibodies. Murine nm23/NDP kinase isotypes increased in regenerating tissue in close association with cellular proliferation including mitotic index. However, the transferred human gene $\mathrm{nm} 23-\mathrm{H} 2$ expressed with different kinetics from murine $\mathrm{nm} 23$, in this study, all fractions of human nm23-H2 molecule responded shortly and strongly. These data suggest that depending on murine or human $\mathrm{nm} 23$, different cellular factors are necessary (Lee et al. 1997b). In transfectant experimemts, murine nm23 transfectant into murine cells has a transcription effect on c-myc and prolongs $S$ phase of cell cycle, whereas those effects in human nm23 transfectant were not shown. That is postulated that cellular cofactor is necessary for nm23/NDP kinase to transactivate the $c-$ myc gene and control the cell cycle. In this study, transcription effect of $n m 23$ was postulated from increased nuclear fraction molecule, and different kinetics of cytoplasmic and membrane protein of transferred human gene $\mathrm{nm} 23-\mathrm{H} 2$ in early phase of hepatic regeneration might show additional functions with cellular cofactor. The difference of their regulatory elements has been reported in both human and rat genomes (Postel et al. 1996). And the two isotypes showed distinct patterns of kinetics indicating independent regulation of their gene expression.

Other observations, excluding PuF and awd gene homology, described previously stated that $\mathrm{nm} 23$ genes linked to cell growth as follows: 1) anti-nm23 antibodies recognize mitotic spindle microtubules (Lakshmi et al. 1993); 2) nm23 is highly homologous to the 19 protein, a neuroblastoma cell proliferationrelated protein (Hailat et al. 1991); 3) microinjection of an nm23-specific antibody inhibits cell division in rat embryo fibroblasts.(Sorscher et al. 1993). However, a direct proof of $\mathrm{nm} 23$ involvement in the cell cycle is still missing.

The transgenic approach involves the permanent introduction of an exogenous DNA sequence into the genome of a host animal. Induction of organ crisis (proliferation) was done by partial hepatectomy, it took around two weeks for recover depending molecular kinetics of nm23 and mitotic index. In terms of regeneration of liver, two isotypes of murine and human $\mathrm{nm} 23$ have regulatory cellular elements respectively. However, organ crisis might bring mobilization and share of different species regulatory elements of nm23/NDP kinase due to close homology between species.

\section{REFERENCES}

Baba H, Urano T, Okada K, Furukawa K, Nakayama E, Tanaka $\mathbf{H}$, Iwasaki $\mathrm{K}$, Shiku $\mathrm{H}$ : Two isotypes of murine $\mathrm{nm} 23$ /nucleoside diphosphate kinase, nm23-M1 and nm23 $-\mathrm{M} 2$, are involved in metastatic suppression of a murine melanoma line. Cancer Res 55:1977-1981, 1995.

Bevilacqua G, Sobal ME, Liotta LA, Steeg PS : Association of low nm23 RNA levels in human primary infiltrating ductal breast carcinomas with lymph node involvement and other histopathological indicators of high metastatic potential. Cancer Res 49:5185-5190, 1989.

Caligo MA, Cipollini G, Fiore L, Calvo S, Basolo F, Collecchi P, Ciardiello F, Pepe S, Petrini M, Bevilacqua G 


\section{- Human nm23-H2 in regenerating transgenic mouse hepatocyte -}

: nm23 gene expression correlates with cell growth rate and S-phase. Int J Cancer 60:837-842, 1995.

Dignam JD, Lebovitz RM, Roeder RG : Accurate transcription by RNA polymerase II in a soluble extract from isolated mammalian nuclei. Nucl Acids Res 11:1475$1489,1983$.

Gilles AM, Presacan E, Vonica A, Lascu I : Nucleoside diphosphate kinase from human erythrocytes. J Biol Chem 266:8784-8789, 1991.

Hailat N, Keim DR, Melhem RF, Zhu X, Eckerskom C, Brodeur GM, Reynold CP, Seeger RC, Lottspeich F, Straheler JR, Hanash SM : High levels of 19/nm23 protein in neuroblastoma are associated with advanced stage disease and with $\mathrm{N}-$ myc gene amplication. $\mathrm{J}$ Clin Invest 88:341-345, 1991.

Higgins GM, Anderson RM : Experimental pathology of liver. 1. Restoràtion of liver of white rat following partial surgical remoyal. Arch Pathol 12:186-202, 1931.

Igawa M, Rukstalis DB, Tanabe T, Chodak GW : High levels of $\mathrm{nm} 23$ expression are related to cell proliferation in human prostate cancer. Cancer Res 54:1313-1318, 1995.

Ishikawa N, Shimada N, Munakata Y, Watanabe K, Kimura $\mathrm{N}$ : Isolation and characterization of a gene encoding rat nucleoside diphosphate kinase. J Biol Chem 267:14366$14372,1992$.

Keim D, Hailat N, Zhu XX, Lascu I, Veron M, Stahler J, Hanash SM : Proliferation-related expression of p19/nm23 nucleoside diphosphate kinase. J Clin Invest 89:919-924, 1992.

Lakshmi MS, Parker C, Sherbet GV : Metastasis associated MTS1 and nm23 genes affect tubulin polymerization in B16 melanomas : a possible mechanism of their regulation of metastatic behavior of tumours. Anticancer Res 13:299$304,1993$.

Lee IH, Okada K, Baba H, Furukawa K, Chang SI, Shiku H : Up-regulation of nm23/NDP kinase expression in regenerating hepatocytes. Int J Oncology 11:965-970, 1997a.
Lee IH, Chang SI, Okada K, Baba H, Furukawa K, Shiku H : Transcription effect of nm23-M2/NDP kinase on $\mathrm{c}-$ myc oncogene. Mol Cells 7:589-593, 1997b.

Okabe-Kado J, Kasukabe T, Hozumi M, Honma Y, Kimura $\mathrm{N}$, Baba H, Urano T, Shiku H : A new function of nm23/ NDP kinase as a differentiation inhibitory factor, which does not require its kinase activity. FEBS Lett 363:311$315,1995$.

Okada K, Urano T, Baba H, Furukawa K, Frukawa K, Shiku $\mathrm{K}$ : Independent and differential expression of two isotypes of human nm23: analysis of the promotor regions of the nm23-H1 and H2 gene. Oncogene 13:1937-1943, 1996.

Postel EH, Weiss VH, Beneken J, Kirtane A : Mutational analysis of nm23-H2/NDP kinase identifies the structural domains critical to recognition of a $\mathrm{c}-$ myc regulatory element. Proc Natl Acad Sci USA 93:6892-6897, 1996.

Sambrook J, Fritsch EF, Maniatis T : Molecular cloning. A labolatory manual. 2nd edit. Cold Spring Harbor Laboratory Press, Cold Spring Harbor, NY pp.7.3-7.52, 1987.

Sorschers SM, Steeg PS, Feramisco JR, Buchmaster C, Boss GR, Meintoth J : Microinjection of an nm23 specific antibody inhibits cell division in rat embryo fibroblasts. Biochem Biophys Res Commu 195:336-345, 1993.

Stahl JA, Leone A, Rosengard AM, Porter L, King CR, Steeg PS : Identification of a second human $\mathrm{nm} 23$ gene, $\mathrm{nm} 23-$ H2. Cancer Res 51:445-449, 1991.

Steeg PS, Bevilacqua G, Kopper L, Thorgirsson UP, Liotta LA, Sobel ME : Evidence for a novel gene associated with Iow tumor metastatic potential. J Natl Cancer Inst 80:200$204,1988$.

Urano T, Takamiya K, Furukawa K, Frukawa K, Shiku K : Molecular cloning and functional expression of the second mouse nm23/NDP kinase, nm23-M2. FEBS Lett 309: 358-362, 1992.

Yamashiro S, Urano T, Shiku H, Furukawa K : Alteration of nm23 gene expression during the induced differentiation of human leukemia cell lines. Oncogene 9:2461-2468, 1994. 


\title{
$\mathrm{nm} 23-\mathrm{H} 2 / \mathrm{NDP}$ kinase $\mathrm{B}$ 유전자이입된 쥐에서 간세포 재생 초기의 조절
}

\author{
이 인 환
}

계명대학교의과대학 해부학교실 및 의학유전연구소

\begin{abstract}
간추림 : 쥐의 간 부분절제후 간셰포의 재생과정에 따른 $\mathrm{nm} 23-\mathrm{M} 1$ 과 $-\mathrm{M} 2$ 표현의 동역학과 세포내 분포 변화 둥은 분열지수와 함께 Lee 등(1997a)에 의해 보고되어있다. 사람형의 nm23-H2가 쥐의 배자에 도입된 생쥐 (transgenic mice)에서 간 재생 과정에 따른 쥐형의 동역학은 위 보고와 아주 유사하였으나 도입된 유전자인 nm23-H2의 밚현은 재생 초기에 대단히 강하고 짧은 기간이었다. 세포분획에서는, 세포질에서도 간부분 절제후 6 시간에 발현의 강한 증가를 보였으나 핵에서 그 변화가 두드러져 간 재생 초기에 외부에서 도입된 사람형 $\mathrm{nm} 23-\mathrm{H} 2$ 의 전사인자로서의 역할이 추정되었다. 이런 변화는 실험실에서 이루어진 결과(Lee 둥 1997b)와는 달 리 중식이 강하게 시작되는 시기 혹은 위혐기(crisis)에는 이 유전자가 전사인자로서 역할을 함에 있어서 다른 유사 세포성 인자와 결합하거나 단독으로 이루어지는 것으로 사료된다.
\end{abstract}

찾아보기 낱말 : nm23/NDP kinase, Transgenic mice, 생쥐, 간세포, 재생, 전사효,과 